
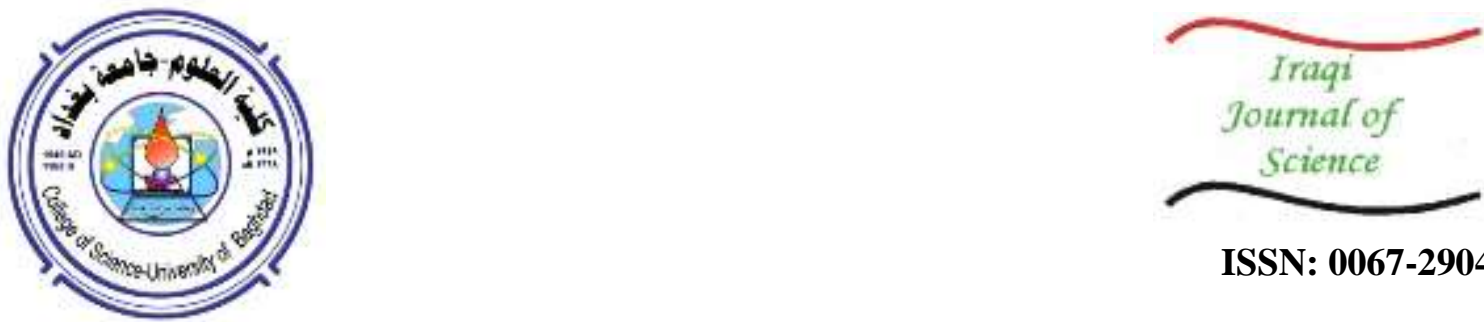

ISSN: 0067-2904

\title{
Evaluation of the Aquifer Properties Between Al-Khassa Dam and Kirkuk Structure - NE Iraq
}

\author{
Shams H. Darwesh*1, Omer S.Al-Tamimi² \\ ${ }^{1}$ Department of Applied Geology, College of Science, University of Kirkuk, Kirkuk, Iraq \\ ${ }^{2}$ Enviromental Researches Unit, College of Science, University of Kirkuk, Kirkuk, Iraq
}

\begin{abstract}
This paper aims to evaluate the hydraulic characteristics of the aquifer between Al-khassa dam and Kirkuk structure, Kirkuk/ NE Iraq. Pumping tests applied for selected wells in the area to evaluate the hydraulic characteristics of the aquifer, special distribution of the water table and groundwater movement direction of the groundwater, the hydraulic properties results of five single pumping test in the study area showed that the transmissivity $(\mathrm{T})$ is ranged between $(2.01$ to 7.5 $\mathrm{m}^{2} /$ day ), storage coefficient $(\mathrm{Sc})$ ranged $\left(6.4 * 10^{-3}\right.$ to $\left.7.3 * 10^{-2}\right)$ and the hydraulic conductivity $(\mathrm{K})$ is ranged between $(0.025$ to $0.35 \mathrm{~m} /$ day) that calculated by Winlog software, groundwater discharge of the area is equal to $0.163 * 10^{6} \mathrm{MCM}$, and the optimum distance between the wells should be about $18.8 \mathrm{~m}$. The results indicated that the aquifer type is semi-unconfined to semi-confined in Bai-Hassan Formation as shown in the geological map. Groundwater movement of the study area showed that the direction of the groundwater is from the East side toward West around (AlKhassa dam area).
\end{abstract}

Keywords: Hydraulic characteristics, Kirkuk, Al-khassa dam, Iraq.

\section{تقييم الخصائص الهياروليكية للمكمن بين سد الخاصة و تركيب كركوك , كركوك شمال شرق العرق}

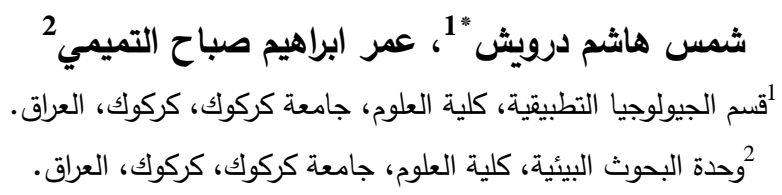

الخلاصة

يهدف هذا البحث الى تقييم الخصائص الهيدروليكية للمكمن بين سد الخاصة و تركيب كركوك, كركوك,

شمال شرق العراق. اجريت عملية الضخ الاختباري لخمس ابار مختارة ضمن منطقة الدراسة لغرض تقييم

الخصائص الهيدروليكية للمكمن المائي و تحديد مناسيب المياه الجوفية لغرض عمل خارطة شبكة الجريان

لمعرفة اتجاه و حركة المياه الجوفية حيث كانت عملية الضخ فردية لكل بئر , بينت الدراسة وجود خزان ضحل فئل

شبه غير محصور ضمن ترسبات العصر الرباعي و وجود خزان شبه محصور ضمن تكوين باي حسن وان

خارطة شبكة الجريان بينت ان اتجاه حركة المياه الجوفية من الاجزاء الثرقية لمنطقة الدراسة باتجاه الاجزاء

الجنوبية الغربية حول منطقة سد الخاصة. تضمنت معلومات تجارب الضخ للآبار الخمسة ان قيمة الناقلية

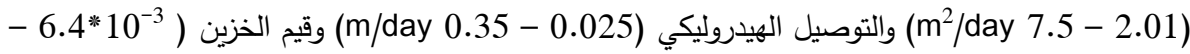

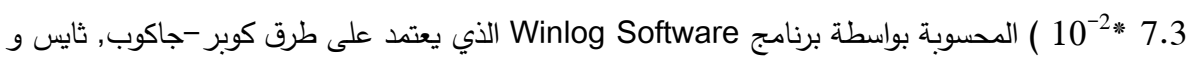

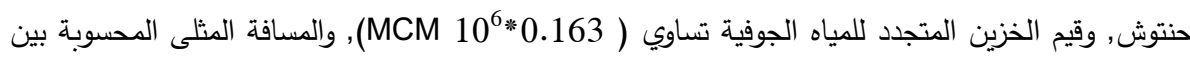

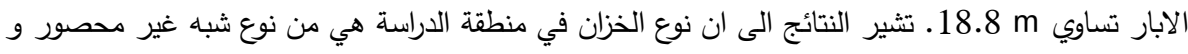

خزان شبه محصور ضمن تكوين باي حسن.

*Email: Shamshd94@gmail.com 


\section{Introduction}

The studies and researches which deals with the groundwater aspects in the area under the influence of dry and semi-dry climate such as current study area is more important, where crisis the water will be more concurrence with decreasing discharge of the rivers, Hydraulic parameters of the aquifers are considered as an essential part of the groundwater studies. The most common effective way of determining these parameters is to conduct and analyze aquifer test, which is a costly method. Alternatively, hydraulic parameters can be found from single wells test especially when observation wells are absent [1].

The study area is located in the northeast of Iraq and northeast of Kirkuk city it is bounded by the coordinates, UTM (3928650 and $3937815 \mathrm{~N})$ in the north and (447096 and $462250 \mathrm{E})$ in the east, it covers about $116 \mathrm{~km}^{2}$ Figure-1. which bounded between AL-Khassa dam in the North and Kirkuk structure from the South-West while from the East bounded with Qarahanjer sub-basin and from the west by Shwan sub-basin, the elevation of study area ranged between $(412-519 \mathrm{~m}$.a.s.l). Groundwater is the main source of agricultural and industrial uses in the study area. Geologically, the area covers by Bai-Hassan Formation is composed of sandstone, siltstone, claystone, and conglomerates. It considered as an independent Formation because of these boulder conglomerates. Formed in a continental environment that resulting from erosion of the high mountains [2], [3]. Bai-Hassan Formation has partly confined aquifer. Recent Quaternary deposits consist of silt, sand, and clay and investing groundwater by drilling shallow wells [4], Figure -2. Tectonically, the study area is located on the unstable Shelf within the foothill zone as part of the ChamChamal - Butma subzone associated with asymmetrical syncline and bounded by Kirkuk structure which extends from NW-SE and consists of faults and joints [5].

The aim of this work is to estimate hydraulic characteristics and groundwater movement in the AlKhassa dam area and estimate the groundwater discharge, and finally suggest the optimum distance between the wells which should depend in the future drilling.

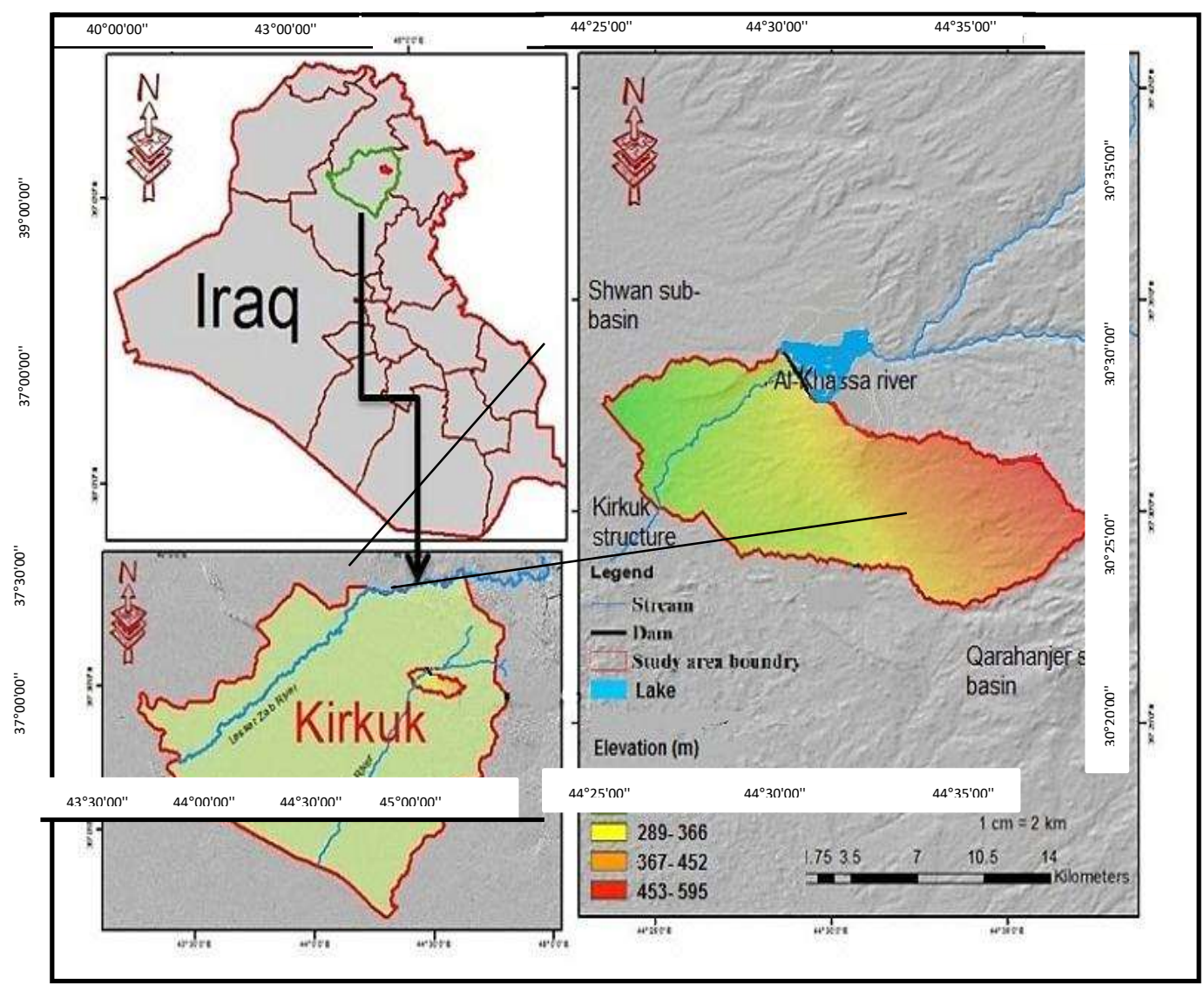

Figure 1-Location map of the study area (Drawn by GIS) 


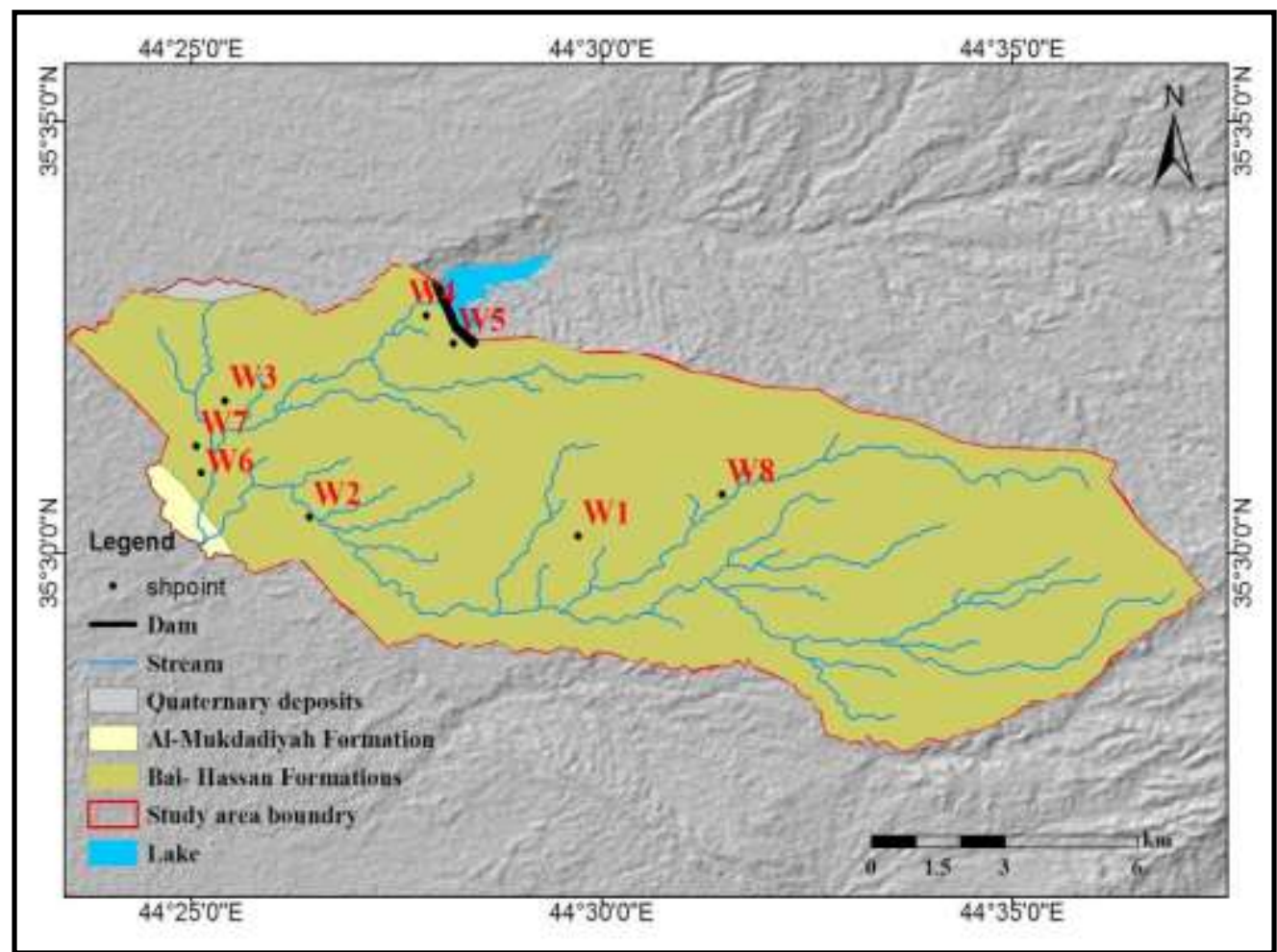

Figure 2-Geological map of the study area [6]

\section{Data \& Methodology}

Five wells in the study area are selected Table -1, to apply single well-pumping test and fieldwork continues during one year to examine through last decay the (water level for each month, collect the samples and pumping test. office work represents combine information of the wells from (General commission of groundwater / Kirkuk) Figure-7, Hantosh [7], Cooper-Jacob [8] and Thies[9] methods were used to analyze the data of pumping test that applied by the researcher to estimate hydraulic properties (Transmissivity $\mathbf{T}$, Hydraulic conductivity $\mathbf{K}$ and Storage coefficient $\mathbf{S c}$ ) of the aquifer in the study area.

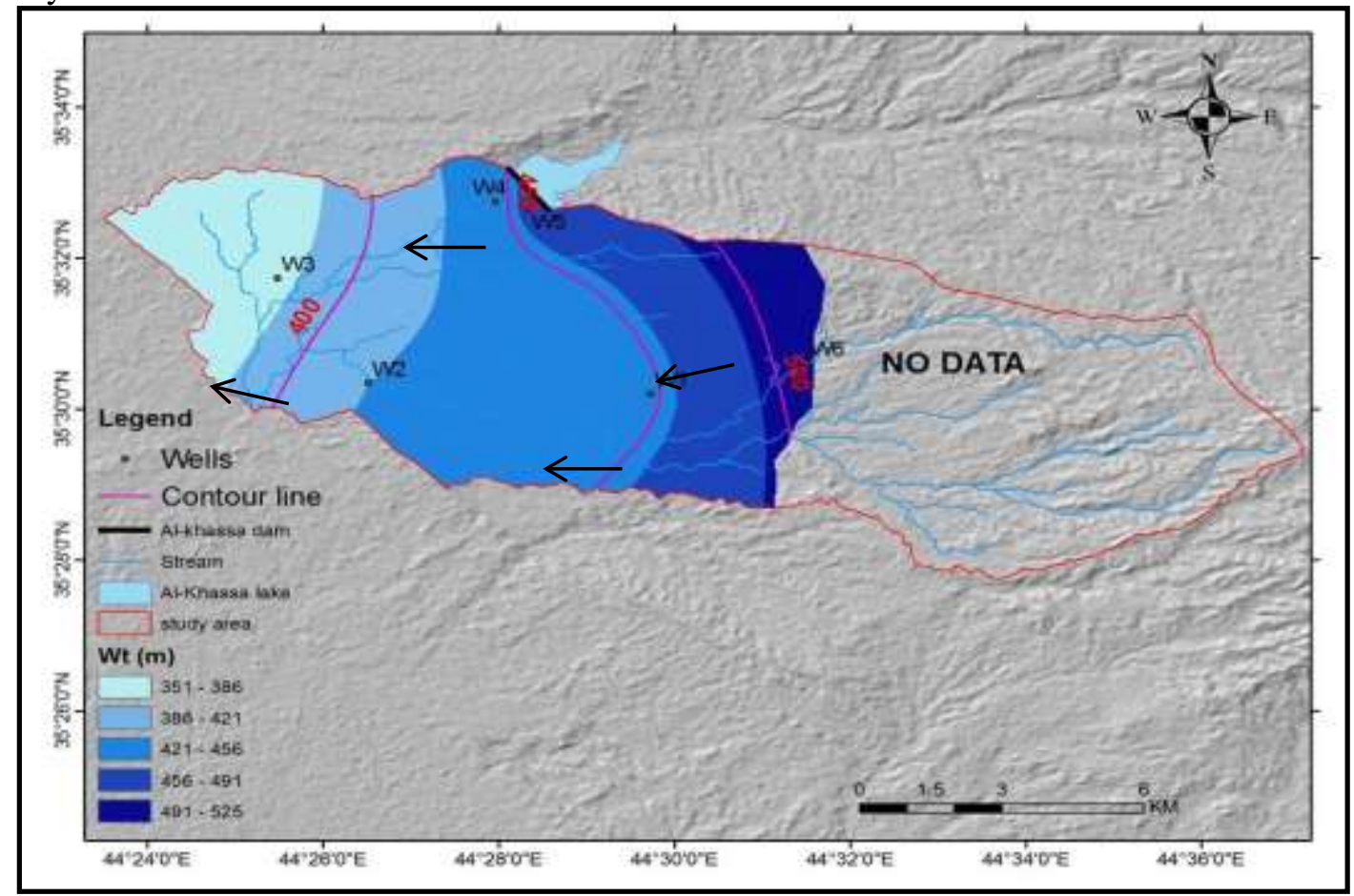

Figure 3-Groundwater map of the study area 
The data of the pumping test shown in Table-1, and the Figure-5 represent relationship between time and drawdown for each pumping test, the interpretation and analyses of the curves to extract the hydraulic properties of the wells in the area as shown in Table-2, and the borehole lithology that obtain from(General commission of groundwater - Kirkuk) to describe the thickness of layers in the wells and the Figures-(4 and 6) that management by starter 3 software and the maps of (T, Sc, and K) shown in Figures- $(7,8,9,10)$ obtain by GIS 10.4 .

Table-1 refers to that the 8 wells depended in the groundwater table flow net and the other wells that determined by $(*)$ refers to pump wells.

Table 1-Coordinate and basic properties of the water wells in the study area

\begin{tabular}{|c|c|c|c|c|c|c|c|}
\hline $\begin{array}{c}\text { Well } \\
\text { no. }\end{array}$ & $\begin{array}{c}\text { well } \\
\text { name }\end{array}$ & $\mathrm{N}$ & $\mathrm{E}$ & $\begin{array}{c}\text { Ground } \\
\text { Surface } \\
\text { Elevation } \\
(\mathrm{m} . \mathrm{a} . \mathrm{s} .1)\end{array}$ & $\begin{array}{c}\text { Well } \\
\text { depth } \\
(\mathrm{m})\end{array}$ & $\begin{array}{c}\text { Depth to } \\
\text { water } \\
(\mathrm{m})\end{array}$ & $\begin{array}{c}\text { W.T } \\
(\mathrm{m})\end{array}$ \\
\hline W1 & $*$ Cheman & $35^{\circ} 30^{\prime} 31^{\prime \prime}$ & $44^{\circ} 29^{\prime} 42^{\prime \prime}$ & 492 & 160 & 32 & 460 \\
\hline W2 & $*$ Dohela & $35^{\circ} 30^{\prime} 21^{\prime \prime}$ & $44^{\circ} 26^{\prime} 30^{\prime \prime}$ & 430 & 75 & 5.65 & 424 \\
\hline W3 & $*$ Yaruali & $35^{\circ} 31^{\prime} 45^{\prime \prime}$ & $44^{\circ} 25^{\prime} 27^{\prime \prime}$ & 412 & 170 & 23.1 & 389 \\
\hline W4 & $*$ Kochak & $35^{\circ} 32^{\prime} 55^{\prime \prime}$ & $4^{\circ} 27^{\prime} 27^{\prime \prime}$ & 519 & 212 & 76.9 & 442 \\
\hline W5 & $*$ Dam & $35^{\circ} 32^{\prime} 39^{\prime \prime}$ & $44^{\circ} 28^{\prime} 20^{\prime \prime}$ & 462 & 200 & 0.4 & 462 \\
\hline W6 & Noorcity & $35^{\circ} 30^{\prime} 55^{\prime \prime}$ & $44^{\circ} 25^{\prime} 7^{\prime \prime}$ & 417 & 63 & 23 & 394 \\
\hline W7 & Sonagul & $35^{\circ} 31^{\prime} 14^{\prime \prime}$ & $44^{\circ} 25^{\prime} 2^{\prime \prime g}$ & 414 & 96 & 43 & 371 \\
\hline W8 & Zawi R. & $35^{\circ} 30^{\prime} 37^{\prime \prime}$ & $44^{\circ} 31^{\prime} 29^{\prime \prime}$ & 513 & 140 & 0 & 513 \\
\hline
\end{tabular}

The figure refers to the four wells instead of well5 because of these data was only available by the general commission of groundwater in Kirkuk.

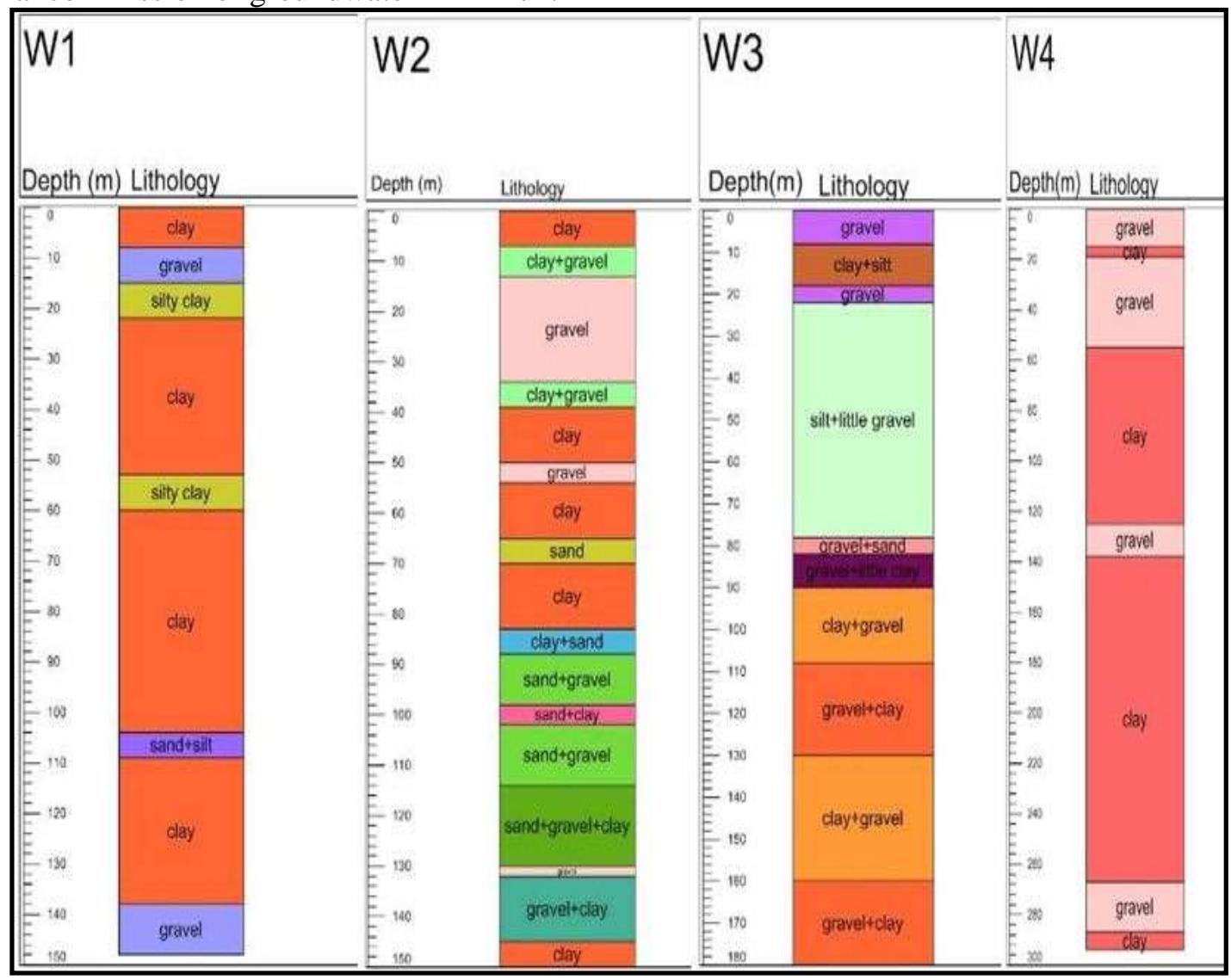

Figure 4-borehole lithology of water wells in the study area 

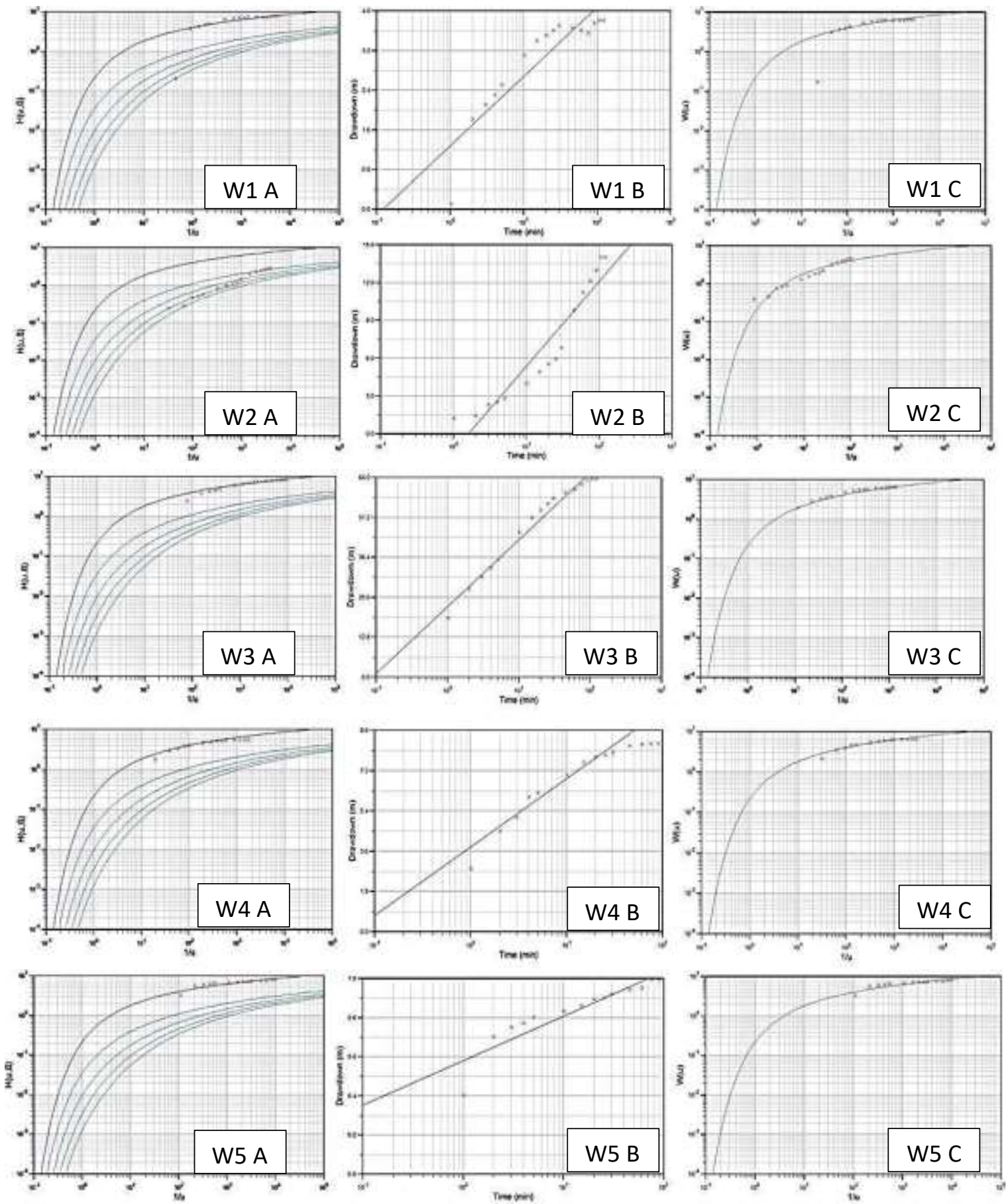

Figure 5-Representing the pumping test data of (W1, W2, W3, W4\&W5) by Hantosh (A), cooper$\mathrm{Jacob}(\mathrm{B}) \&$ Thies $(\mathrm{C})$ analysis in the study area

\section{The Results}

Pumping test process carried out for five single wells distributed to cover the study area with constant discharge Figure-6. Observation wells are not available in the studied area, therefore these tests have been conducted without observation well as shown in Figure-3. The data of pumping test and graphs of the pumping test wells in the study area Figure-5. From the graphs in the Figure-5 it can be observed that the data analysis of pumping test by Jacob, Thies, and Hantosh reflect the existence of one layer, which it showed the existence of gravel layers successive with the clay within Bai-Hassan Formation. The groundwater table in the study area illustrated that the aquifer has hydraulic head $462 \mathrm{~m}$ in well no.5 to hydraulic head $389 \mathrm{~m}$ in well no.3. the general direction of the groundwater in the study area movement from the east toward the southwest, Figure-2. The average value of hydraulic 
properties reflects that the values of Bai-Hassan aquifer in the study area are heterogeneous and anisotropy due to variations in lithology and porosity of the aquifer.

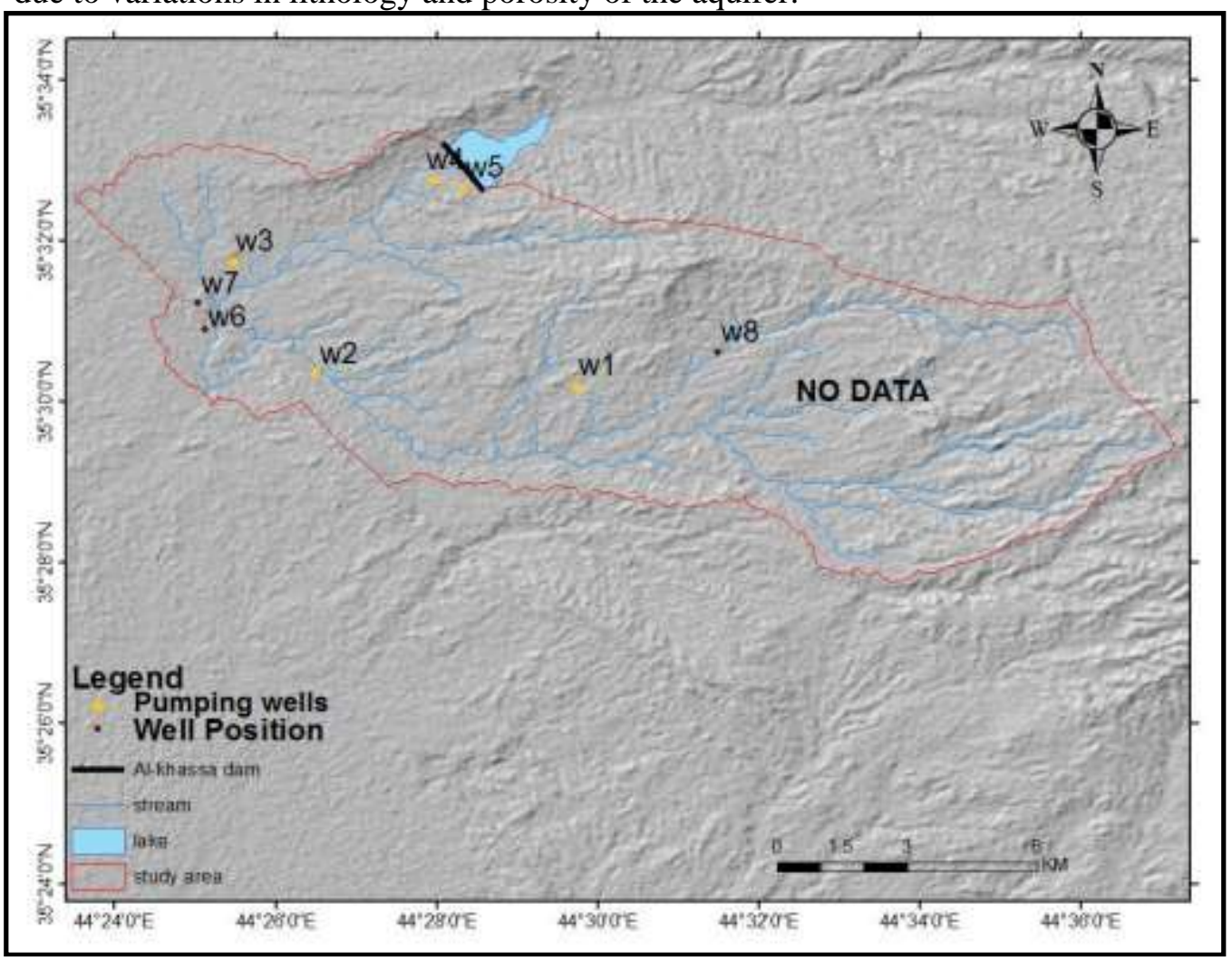

Figure 6-Locations of the pumping wells in the study area

The natural discharge in the study area of the groundwater in the aquifer is toward the west side. An essential part of the water balance which is represented in outputs of the area, determined from Darcy law[10] that equal to $\mathrm{Q}=\mathrm{iAT}, \mathrm{i}=\mathrm{dh} / \mathrm{L}$ where :

$\mathrm{i}=$ hydraulic gradient determined from the height difference between two points from the recharge to the discharge area.

$\mathrm{A}=$ area of the flow section $\left(\mathrm{m}^{2}\right)$

$\mathrm{T}=$ total transsmisivity $\left(\mathrm{m}^{2} /\right.$ day $)$

$\mathrm{Q}=$ discharge of the area $\left(\mathrm{m}^{3} /\right.$ day $)$

$\mathrm{i}=100 / 7900=0.01265$

$\mathrm{Q}=0.01265 * 7900 * 4.483=448 * 365=163520 \mathrm{~m}^{3} /$ day

The results of the pumping test refer to that the transmissivity of W4 is height because of the well is very close to Al-Khassa reservoir which may affect the well by leakage. Saturated thickness of this well $84 \mathrm{~m}$ The optimum distance between the water wells was calculated as the following formula [11]:

$\mathrm{R}=2 * \sqrt{ }((\mathrm{T} * \mathrm{t}) / \mathrm{Sc})$

And the distance that should be between each well equal to 18.85 .

Table 2-Hydraulic characteristic of the aquifer in the study area

\begin{tabular}{|c|c|c|c|c|c|}
\hline Wells & $\mathrm{T}\left(\mathrm{m}^{2} /\right.$ day $)$ & $\mathrm{Sc}$ & $\mathrm{K}(\mathrm{m} /$ day $)$ & $\mathrm{Q}\left(\mathrm{m}^{3} /\right.$ day $)$ & $\begin{array}{c}\text { Saturated } \\
\text { thickness }(\mathrm{m})\end{array}$ \\
\hline $\mathrm{W} 1$ & 7.5 & $6.4 * 10^{-3}$ & 0.357 & 57.02 & 21 \\
\hline $\mathrm{W} 2$ & 2.01 & $7.3 * 10^{-3}$ & 0.025 & 64.8 & 82 \\
\hline $\mathrm{W} 3$ & 4.1 & $6.6 * 10^{-3}$ & 0.056 & 432 & 73 \\
\hline W4 & 457.3 & $6.4 * 10^{-2}$ & 5.444 & 576 & 84 \\
\hline W5 & 6.73 & $7.1 * 10^{-2}$ & 0.089 & 119.23 & 75 \\
\hline
\end{tabular}




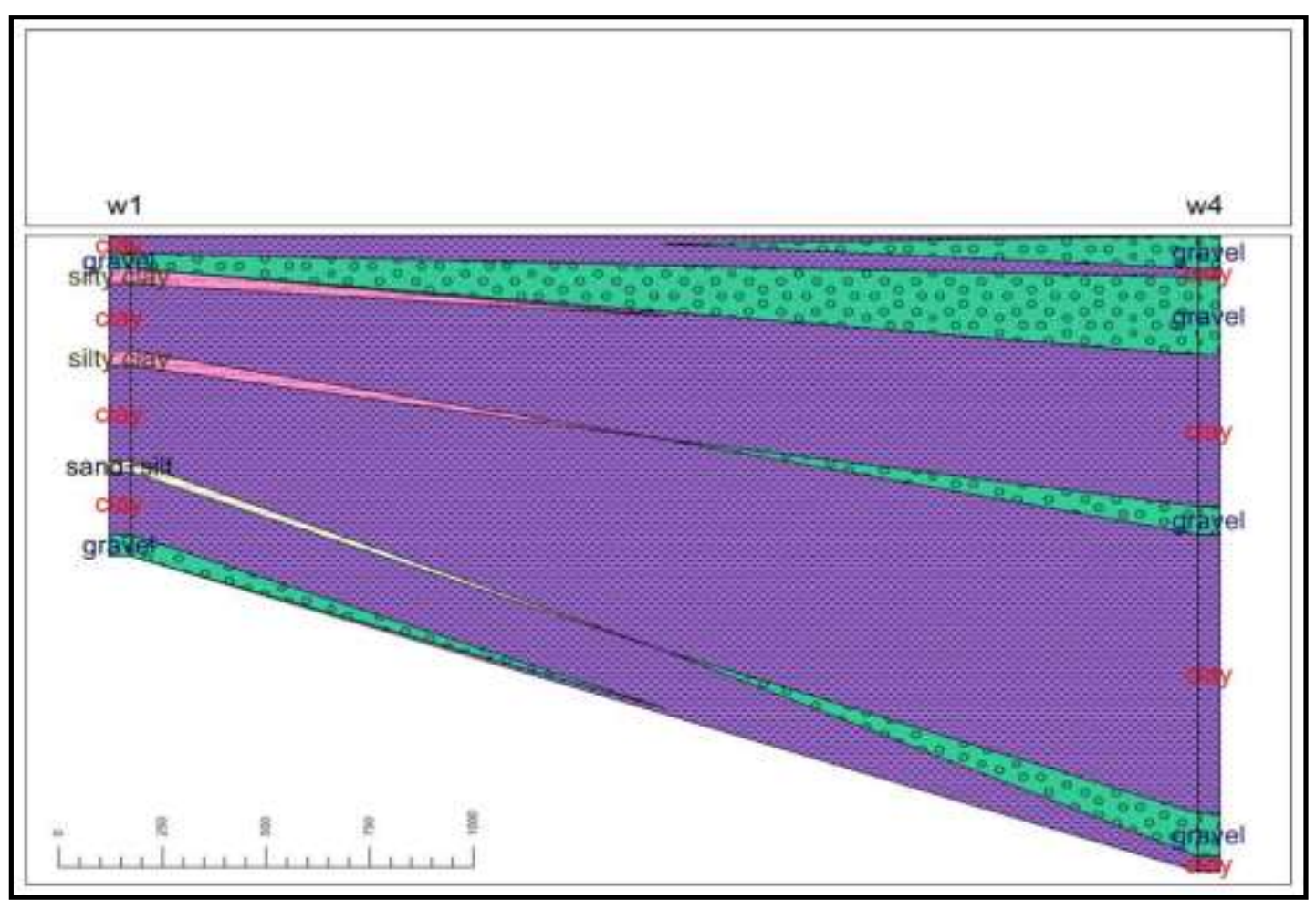

Figure 7-Lithological cross-section between (W1 - W4) in the study area

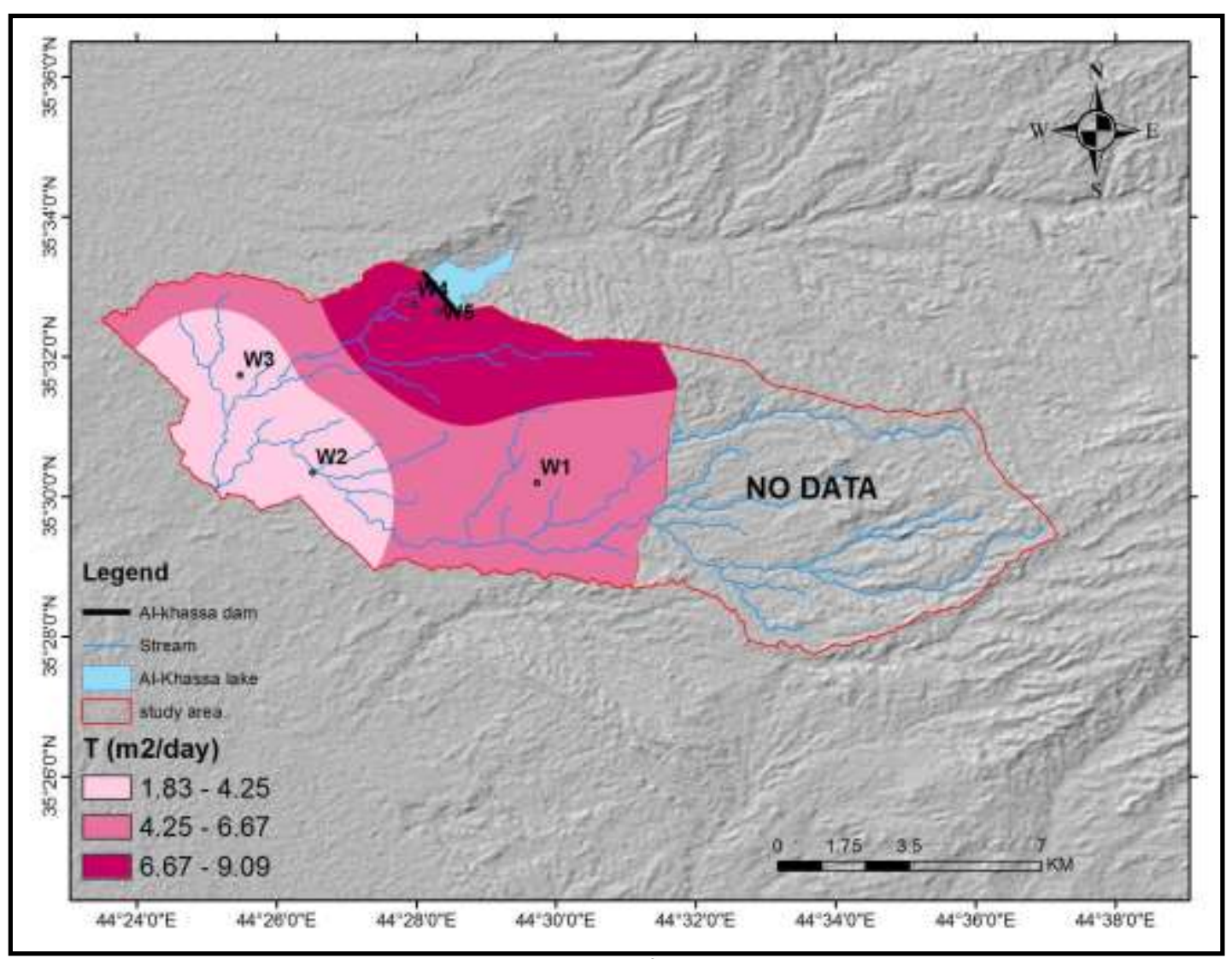

Figure 8-Transmissivity $\left(\mathrm{m}^{2} /\right.$ day $)$ of the study area 


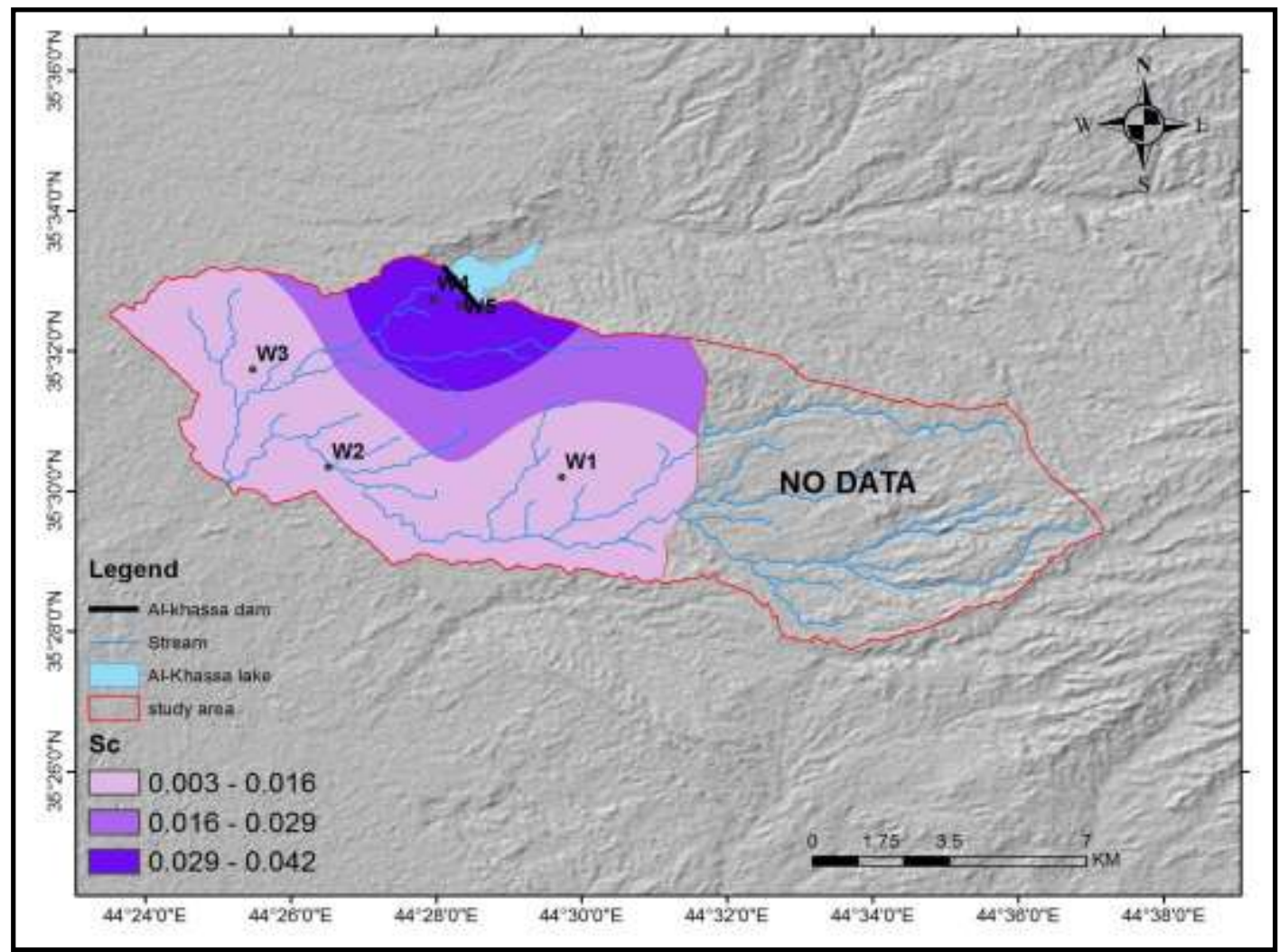

Figure 9-Storage coefficient of the study area

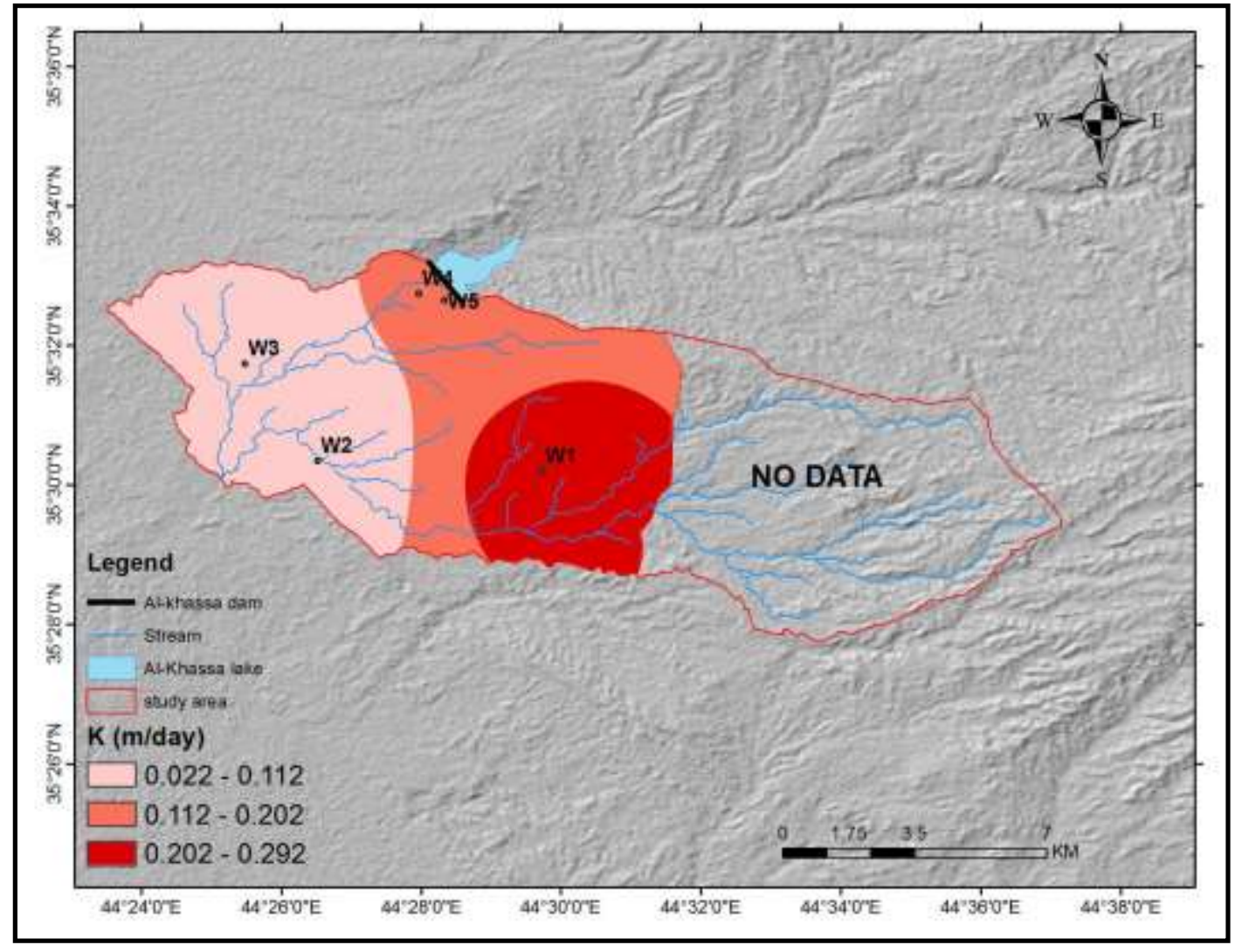

Figure 10- Hydraulic conductivity (m/day) of the study area 


\section{Conclusion}

Groundwater hydraulic characteristic determining by analyzing the data of pumping test of five wells distributed in the study area by Thies and Cooper-Jacob methods shown that the transmissivity (T) ranged between $\left(2.01\right.$ to $7.5 \mathrm{~m} 2 /$ day ), storage coefficient $(\mathrm{Sc})$ between $\left(6.4 * 10^{-3}\right.$ to $7.3 * 10^{-2}$ ) that calculated from radius of the wells and hydraulic conductivity and $(\mathrm{K})$ ranged between $(0.025$ to $0.357 \mathrm{~m} /$ day ) these value are differed from well to another because of lithology heterogeneous in the aquifer. Groundwater map of the study area are referred to a direction of groundwater movement is from Eastside to the west Al-Khassa dam area and type of the aquifer is semi-unconfined to semiconfined. In addition that the cross-section of the aquifer in the study area clarifies the same type of aquifer. Darcy law applied on the groundwater map to estimate hydraulic gradient and discharge of the study area that represented by the discharge of the basin and Q was equal to $163520 \mathrm{~m}^{3} / \mathrm{day}$. As well as there is the clear effect of the dam on the study area and that appear in W4 due to the well penetrate the lake basin. And the distance that should be between each well equal to $18.85 \mathrm{~m}$ and this should be depended in the future of the drilling

\section{References}

1. Kruseman, G .P. and de Ridder, N.A. 2000. Analysis and Evaluation of ofTest Data. International Institute for Land Reclamation and PumpingImporovement, Wageningen, the Netherlands, 372p.

2. Buday, T. 1980. Regional Geology of Iraq stratigraphy and paleogeography state organization of minerals, Baghdad, $445 \mathrm{p}$.

3. Barwary, A. M. and Slewa, N. A.1995.The geology of Samarra Quadrangle sheet NI-38 -6, scale 1: 250000, GEOSURV. Lib. Rept. No. 2227, Baghdad, Iraq.

4. Al-Naqash, A. B., Ismaeel, S. Kh., Hasan, A. H. and Rahi, Kh. M. 2003. Evaluation study and setting of production program for wells of national campaign project for water well drilling in Kirkuk governorate, internal report, Ministry of irrigation, General company for water well drilling, 185 p. (In Arabic).

5. Buday, T. and Jassim S.Z. 1987. The regional Geology of Iraq. Vol. 2, Tectonism, Magmatism and Metamorphism, 352p.

6. Sissakian, V.K. 1992. The Geology of Kirkuk Quadrangle, sheet NI-38-2, Scale 1: 250000. GEOSURV, Baghdad, Iraq.

7. Hantosh, H.A., Hassan H.M., Ahmad, B. and Al-fatlawy, A. 2009. Mosquito species geographical distribution in Iraq 2009. J Vector Borne Dis. 2012; 49: 33-5.

8. Theis, C.V.1935.ThebLoweringbpiezometric the surface and the rate and discharge of a well-using water storage transaction American Geophysicalunion. 16: 519-24.

9. Cooper, H.H. and Jacob, C.E. 1946. Drawdown test to determine effective of an artesian well. Transe. Amer., Civil Eng., 115.

10. Kruseman, G .P. and de Ridder, N.A. 2000. Analysis and Evaluation of ofTest Data. International Institute for Land Reclamation and Pumping Imporovement, Wageningen, the Netherlands, 372p.

11. Abdul Razzaq, M. I., Ahmed, A. M. and Uroba, A. 2007. Hydrogeological Study for the Upper Al-Adhaim Basin, internal report, Ministry of water resources G.D.F. Management of water resources, Groundwater Study Center.260 p. (In Arabic). 